\title{
REPORT ON THE INTERNATIONAL SCIENTIFIC CONFERENCE “INVITATION UNDERSTANDING PUBLIC BUREAUCRACY” \\ (11-12 June 2018, Budapest, Hungary)
}

The National University of Public Service with the support of the Center for Information and Research Organization on Public Finances and Tax Law in the Countries of Central and Eastern Europe held a twoday conference to exchange ideas and experience connected with the concept of public bureaucracy, as applied public governance and public administration in the countries of Central and Eastern Europe.

The conference was opened by Dr. habil. Györgyi Nyikos who welcomed the renowned international guests and wished a successful discussion to the participants. The Vice-Rector for International Affairs also talked about the history of Ludovika, the structure of NUPS and the missions of the university. She emphasised that the aim of the university, among others, is to promote the cooperation between public and private entities and to continuously conduct researches on current issues.

Elena Kireeva from the Russian Presidential Academy of National Economy and Public Administration (RANEPA) talked about the concept of good governance in jurisprudence through the Russian experience and practice. According to the expert, the concept of good governance is a key factor in decreasing bureaucracy. She also elaborated the ongoing developments in the Russian public administration such as the administrative websites and multifunctional customer service centres which helped to decrease waiting time.
Prof. Dr. Norbert Kis presented the future scenarios of public bureaucracies. The Dean of the Faculty of Political Sciences and Public Administration of NUPS quoted the famous Danish physicist during his presentation, "Prediction is very difficult, especially if it is about the future." The Dean explained the post-bureaucratic era and the term of dataism. The latter determines all the processes, including those related to public administration, only as a set of data for analysis. While closing his session, Norbert Kis described bureaucracy as a wall between the citizens and public servants which can be dismantled by reducing the bureaucracy. The Good Governance report prepared by NUPS serves this purpose as well.

Juraj Vačok, representative of the Comenius University, Slovakia, reviewed a new legal regulation of administrative justice in the Slovak Republic, focusing mainly on the changes and processes from the past two years. After this section, Piotr Buława from the University of Silesia, Poland, described the participation of tax authorities in insolvency agreements. According to the specialist the public administration system in Poland is too bureaucratic and less flexible while on the other hand, the German system is a good example because the state income is allocated based on the resources used on collection and there is a long-term plan, unlike in the Eastern Europe. 
The other presenters of the morning session were Wojciech Piątek from the Polish Adam Mickiewicz University, Krisztina Rozsnyai from the Eötvös Loránd University, Anna Románová from the Pavol Jozef Šafárik University and Matej Horvat from the Comenius University.

On the second day of the Conference a panel discussions was organized with the participation of experts from Hungary, Czech Republic, Slovakia and Poland, where selected issues of financial law and the current legal challenges were discussed.

The following institutes of higher education were represented at the conference: University of Zagreb, Faculty of Law (Croatia); Jan Długosz University (Poland); RANEPA - Russian Presidential Academy of National Economy and Public Administration (Russia); Masaryk University, Brno (the Czech Republic); Charles
University, Prague (the Czech Republic); Palacký University, Olomouc, Faculty of Law (the Czech Republic); University of Szczecin (Poland), University of Białystok (Poland); University of Silesia (Poland); Universidad de León (Spain); Uniwersytet Wrocławski (Poland); Kozminski University Warsaw (Poland); Supreme Administrative Court of Poland; Nicolaus Copernicus University in Toruń (Poland); Polish Academy of Sciences, Institute of Law Studies; Adam Mickiewicz University in Poznań (Poland); Pavol Jozef Šafárik University in Košice (Slovakia); Comenius University in Bratislava (Slovakia); University of Finance and Management in Bialystok (Poland); WSB University in Toruń (Poland); University of Łódź (Poland); Technical University of Ostrava (the Czech Republic); University of Gdańsk (Poland) and Yanka Kupala State University (Grodno, Belarus). 